Uluslararası Yönetim İktisat ve İsletme Dergisi, ICAFR 16 Özel Sayısı

Int. Journal of Management Economics and Business, ICAFR 16 Special Issue

\title{
DEVELOPMENTS, TRENDS AND FEATURES OF FINANCIAL INTEGRATION IN THE WESTERN BALKAN REGION- CROSS- COUNTRY COMPARISONS
}

\author{
Assoc. Prof. Dr. Mehmed GANić \\ Faculty of Business Administration, International University of Sarajevo \\ mganic@ius.edu.ba \\ Assoc. Prof. Dr. Agim MAMUTi \\ Faculty of Business and Economics, University of New York in Tirana (UNYT) \\ agim.mamuti@yahoo.com
}

\begin{abstract}
This paper looks at the key trends of financial integration and analyzes the degree to which Western Balkan countries are internationally integrated in financial flows. With the aim of reviewing the development of financial integration in the region some the experience of Western Balkan regions will be examined by conducting cross-country comparisons. The analysis focuses on the Western Balkans region by examining a set of financial indicators, but it will be useful to see the comparative view to the European perspective (EU 3 countries). To the purpose of cross country comparison, several important financial integration indicators related to financial openness and financial deepening are considered. The data for eight transition countries was sourced from the World Bank - World Development Indicators, IFS (International Financial Statistics), and WEO. For needs of the size and composition of capital inflows countries of the Western Balkan and EU 3 countries data are drawn from balance of payment selected countries. The paper provides two key insights. First, the financial systems in sample of analyzing countries are still at an earlier stage. Second, the median volatility of Portfolio investments (as \% of GDP) is shown substantially less than the median volatility of Loanto-GDP ratio and median volatility of FDI flows-to-GDP ratio. Also, the coefficient of variation for the Western Balkan region as well as EU3 countries reveals that the loanto-GDP ratio is less volatile than the FDI inflows to GDP ratio.
\end{abstract}

Keywords: international financial integration, financial openness, capital inflows, cross country analysis, financial development.

\section{Introduction}

In 1990s, all countries of Western Balkan have experienced the economic difficulties and stagnation of output when entered into a phase of increasing economic and political uncertainty. However, the early of the 2000s have seen gradual processes of political and economic transformation the countries of Western Balkan from a central planned economy to a market oriented one. The financial system was accompanied by these changes and the financial landscape of the region has changed significantly. National financial systems are re-established at the legacy of hyperinflation, which was completely destroyed confidence in the system of financial intermediation and security 


\section{Uluslararası Yönetim İktisat ve İşletme Dergisi, ICAFR 16 Özel Sayısı Int. Journal of Management Economics and Business, ICAFR 16 Special Issue}

savings in 1990s (Serbia and Montenegro). By comparing the transitional experience of some countries it can be concluded the Western Balkan region lag many years behind of the advanced transition countries (CEE countries) measured by the transition indicators. The problems faced by reformers in the Western Balkan region in the early stage of transition are widening disparities in levels of economic development across the region as well as social problems and macroeconomics instability. Consequently, all countries of the Western Balkans have an underdeveloped economic system. The dynamics of international financial integration in the late 1990s have coincided with a growing internationalization of business activities, as well as a general capital liberalization and deregulation of domestic financial markets. Accordingly, some authors see the liberalization of capital flows as one of the most important assumptions for the increasing international financial integration (Mirdala, R., 2008 and Brezigar-Masten, A. et al., 2010). The economies of the Western Balkans are in the process of transition from a planned economy to a market oriented one. In recent years, in order to politically stabilize the region, convergence towards EU standards is seen as a desirable goal which should contribute to the economic prosperity and development. However, regardless of the results achieved, as well as the existing differences in the level of economic development that exist from country to country, it can be concluded that it is necessarily a certain time in order to "catch" progress in reducing their economic development gap with EU members. The process of restructuring in the financial sector and the real sector of the Western Balkans has advanced significantly. The new phase of the financial and economic development is in progress, and EU candidate countries (Macedonia, Serbia, Albania and Montenegro) as well as the status of a potential candidate country, (B\&H and Kosovo) should continue to progress in the right direction. A crucial challenge in this process is the needs of improvement "functioning market economy and capacities to cope with competitive pressure", as one of the Copenhagen criteria for EU accession. This seems to indicate that the current compliance framework requires further strengthening of the financial sector in the aspiring countries of the region aspiring to regional integration and EU membership. Accordingly, the question arises now: What is the role of the financial sector in the functioning of the economy?

\section{Theoretical Background}

The integration of financial markets is being implemented in order to move towards economic growth. Numerous studies have proven the relation of FDI and economic growth to exist. Some previous studies widely discussed over the past decades about the extent to which financial integration and financial development are linked to economic growth, but the theory has not reached a clear consensus and remains a matter of debate. One of the first empirical researches on financial integration was carried out by Feldstein \& Horioka (1980). The authors have examined the link between domestic savings rate and domestic investment in the context of financial integration in 1970s. In addition, regarding of liberalization of the capital market, they examined the mobility of international capital in the long term on the basis of the association between investment and saving in OECD countries. Furthermore, the same authors have studied the possibilities of government and private borrowing on the integrated financial market under the assumption of lower domestic saving. One of the points of their study is that under the assumption of perfect capital mobility and unaffected investment opportunities, the increasing of domestic saving growth rate results in an increase of investment in all 


\author{
Uluslararası Yönetim İktisat ve Işsletme Dergisi, ICAFR 16 Özel Saylsı \\ Int. Journal of Management Economics and Business, ICAFR 16 Special Issue
}

analyzed countries covered by the study. In other words, the low correlation coefficient between domestic savings rates and level of investment indicates a high level of financial integration. This relationship was tested several times and is considered basic for understanding the macroeconomic effects of the integration of capital markets (Feldstein $\&$ Bacchetta, 1991). Alfaro at.al (2004) were looked for the nature of relations amongst FDI inflows, financial markets and economic growth in some selected countries covering a period between 1975 and 1995. The study examined whether countries with better financial systems can exploit foreign direct investment more efficiently. The authors found that countries with well-developed financial markets get significant benefits from FDI inflows. Moreover, the study Capital Account Liberalization: What Do CrossCountry Studies Tell Us? written by Eichengreen, (2001) advocates that the portfolio investment is one of indicators of the financial integration and that portfolio investment should encourage efficiency and economic growth. Aizenman et al. (2012) investigated -relationship between economic growth and lagged international capital flows, by focusing on FDI, portfolio investment, equity investment, and short- term debt. The study covers the sample of 100 countries in the time period between 1990 and 2010. The findings indicate that the coefficient of portfolio investment is negative and statistically insignificant. Another study written by Vo (2005) empirically investigates the potential drivers of international financial integration together with policy on capital controls and other components of financial structure (the level of economic and educational development, economic growth, the institutional and legal environment, trade openness, and financial development and tax policy). The variable the GDP was used as a control variable to examine the effect of economic growth on the level of international financial integration. Vo concluded that some variables such as GDP, economic growth are effective candidates to act as drivers of international financial integration. Lane \& MilesiFerretti, (2003) explores the extensive trends in international financial integration by using set of 18 member countries of the Organisation for Economic Cooperation and Development (OECD) over the period from 1978 to 2001. Furthermore, the authors examine the behaviour of the rates of return on foreign assets and liabilities, relating them to "market" returns. In the analysis, they used three indicators of domestic financial development, which eventually might boost economic growth are: the ratio of liquid liabilities to GDP, the ratio of stock market capitalization to GDP, and the ratio of cumulative privatization revenues to GDP. The findings or regressions reveal that the ratio of liquid liabilities to GDP is positive and marginally significant.

\title{
3. An Overview Recent Economic Trends
}

The process of international financial integration in Western Balkan countries has moved a slower pace than in other advanced transition countries by the gradual elimination of capital account restrictions and deregulation of financial markets. In addition, cross-country comparisons over time reveals that the average rate of government debt in the first sub period between 2000 and 2005, grew faster than in two others sub periods. 
Uluslararası Yönetim İktisat ve İşletme Dergisi, ICAFR 16 Özel Sayısı

Int. Journal of Management Economics and Business, ICAFR 16 Special Issue

Table 1. Cross-country comparisons of selected macroeconomic indicators, 20002015

\begin{tabular}{|c|c|c|c|c|}
\hline & & $2000-2005$ & 2006-2010 & 2011-2015 \\
\hline \multirow[b]{6}{*}{ Albania } & Real GDP growth (per cent) & 6 & 5.18 & 2.02 \\
\hline & Investment (per cent GDP) & 36.74 & 34.08 & 30.41 \\
\hline & $\begin{array}{l}\text { Gross national Savings (per cent } \\
\text { GDP) }\end{array}$ & 29.22 & 22.16 & 18.34 \\
\hline & Inflation, percent change & 2.83 & 2.96 & 1.77 \\
\hline & General government gross debt & 12.13 & 12.64 & 9.94 \\
\hline & Current account balance & -7.52 & -15.4 & -13.4 \\
\hline \multirow[b]{6}{*}{$\mathrm{B} \& \mathrm{H}$} & Real GDP growth (per cent) & 4.37 & 3.07 & 1.062 \\
\hline & Investment, (per cent GDP) & 27.15 & 21.04 & 17.74 \\
\hline & $\begin{array}{l}\text { Gross national Savings (per cent } \\
\text { GDP) }\end{array}$ & 12.13 & 12.64 & 9.94 \\
\hline & Inflation, percent change & 2.1 & 3.27 & 0.8 \\
\hline & General government gross debt & 29.96 & 29.13 & 43.02 \\
\hline & Current account balance & -16.92 & -8.84 & -8.11 \\
\hline \multirow[b]{6}{*}{ Macedonia } & Real GDP growth (per cent) & 2.43 & 4.01 & 2.3 \\
\hline & Investment, (per cent GDP) & 25.98 & 22.86 & 20.17 \\
\hline & $\begin{array}{l}\text { Gross national Savings (per cent } \\
\text { GDP) }\end{array}$ & 19.06 & 18.88 & 27.3 \\
\hline & Inflation, percent change & 15.84 & 2.98 & 1.85 \\
\hline & General government gross debt & 48.48 & 24.5 & 34.19 \\
\hline & Current account balance & -5.27 & -5.79 & -2.36 \\
\hline \multirow[b]{6}{*}{ Montenegro } & Real GDP growth (per cent) & 2.82 & 4.59 & 1.75 \\
\hline & Investment, (per cent GDP) & 19.03 & 29.96 & 20.64 \\
\hline & $\begin{array}{l}\text { Gross national Savings (per cent } \\
\text { GDP) }\end{array}$ & 9.28 & -3.85 & 3.2 \\
\hline & Inflation, percent change & 12.52 & 3.97 & 1.92 \\
\hline & General government gross debt & 48.48 & 33.51 & 57.21 \\
\hline & Current account balance & -11.09 & -34.27 & -16.66 \\
\hline \multirow[b]{6}{*}{ Serbia } & Real GDP growth (per cent) & 6.48 & 2.72 & 0.32 \\
\hline & Investment, (per cent GDP) & 21.27 & 24.47 & 18.32 \\
\hline & $\begin{array}{l}\text { Gross national Savings (per cent } \\
\text { GDP) }\end{array}$ & 15.84 & 12.38 & 11.08 \\
\hline & Inflation, percent change & 29.15 & 8.43 & 5.12 \\
\hline & General government gross debt & 99.2 & 37.14 & 63.05 \\
\hline & Current account balance & -5.44 & -12.1 & -7.23 \\
\hline
\end{tabular}

Source: IMF, World Bank Database, WEO data, 2015.

Furthermore, with the exception of Macedonia, the level of national savings as a percentage of GDP in other countries of the region fall and continue falling. The highest 


\section{Uluslararası Yönetim İktisat ve İsletme Dergisi, ICAFR 16 Özel Sayısı Int. Journal of Management Economics and Business, ICAFR 16 Special Issue}

level of national savings measured by percentage of GDP was recorded in Macedonia (27.30\%), and Albania (18.34\%). As regards the Western Balkans examples, with the exception of Albania, the share of investment in GDP in most countries does not exceed $20 \%$. However, last one reveals that it is not sufficient to the boost Western Balkan's growth potential and reduction of unemployment rate.

\section{The Regional Dimension of Financial Openness}

Generally speaking, economies strive to achieve economic growth and development. In order to reach the economic growth capital has to be present. Lacking of adequate capital in transition economies leaves no space for many options; foreign capital needs to be attracted. Assets and Liabilities as a Share of GDP is the most widely used indicators in assessing level of financial integration and financial openness of any country. As a result of the increased movement of capital flows there is a positive development in the field of international financial integration Western Balkans region over time. Although the Western Balkan region as a whole has a lower ratio of of financial openness (measured by international assets and liabilities to GDP) in comparison to Bulgaria and Croatia, recent years have seen a moderate progress. All the Western Balkan countries are a diverse group with varying degrees of financial openness. Assets and Liabilities as a Share of GDP for the countries of the Western Balkans and EU 3 countries (Bulgaria, Croatia, and Romania) for the period from 1998 through 2011 is illustrated in Figure 1. In all analyzed countries the share of foreign assets and liabilities as a percentage of GDP has been increased from period to period. The period from 1998 to 2005 may be considerate as a first stage of rapid financial integration in the Western Balkan region. Between 2005 and 2011 the financial openness in the region of has witnessed a significant rise. By the same token, in the second sub period, the average value of this ratio exceeded $100 \%$ of GDP, but in the case of Montenegro and over $200 \%$ of GDP. By contrast, Albania has the lowest share of Assets and Liabilities to GDP. Over the reference period, all countries from our sample have increased its foreign assets and liabilities to GDP ratio. For example, the foreign assets and liabilities to GDP ratio in some countries as Serbia (170.47\%), and Montenegro (214.8\%) are closer to the group of the EU 3 countries.

Figure 1 Financial openness by selected transition countries

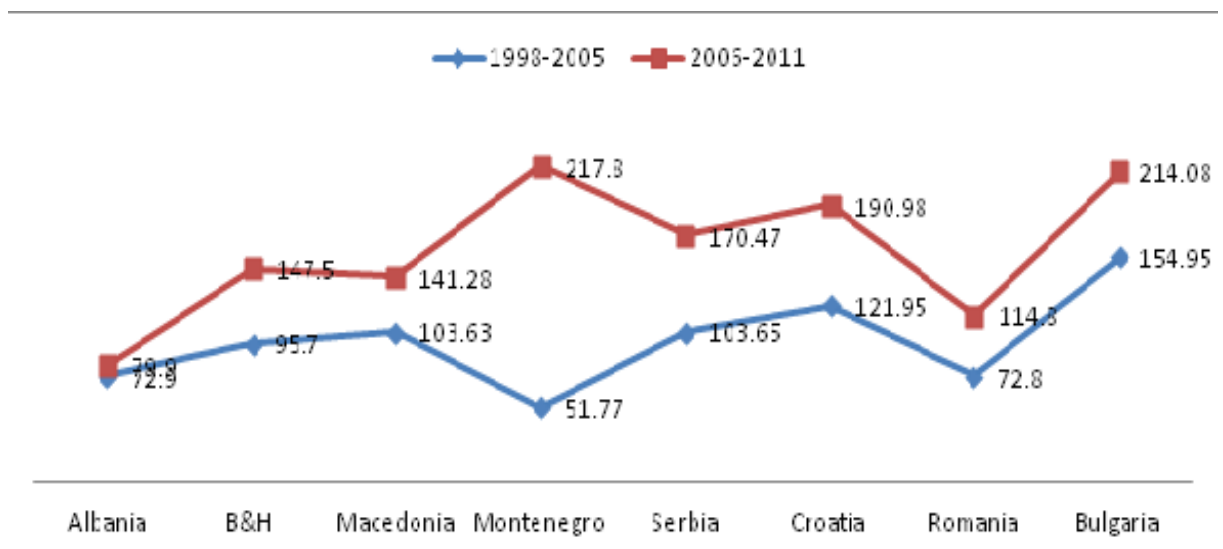

Source: author's elaboration on Lane and Milesi-Ferretti (2011) data and IFS 


\section{Uluslararası Yönetim İktisat ve İsletme Dergisi, ICAFR 16 Özel Sayısı Int. Journal of Management Economics and Business, ICAFR 16 Special Issue}

Also as shown in figure 2 the dynamics of growth of foreign assets and liabilities in certain countries of the Western Balkans (Montenegro and Bosnia and Herzegovina) is even higher than in the new EU3 countries for the period 1998-2011. Overall, international financial openness of the country was constantly growing during the reference period. As expected, the average growth rate of financial openness exceeded the average GDP growth rate in most of analyzed countries with the exception in Albania, Serbia and Bulgaria. Moreover, the average growth rate of financial openness in Montenegro and Bosnia and Herzegovina over the same period grew on average $15.3 \%$ and 6.37 respectfully\%. These two countries, along with Romania have achieved the most dynamic growth in the international financial openness. The remaining countries form sample is far less financially integrated (Macedonia, Serbia and Bulgaria) and below average of financial openness's rate for the whole region $(5.7 \%)$.

Figure 2 Cross country comparison of average growth rate financial openness's by countries, 1998-2011.

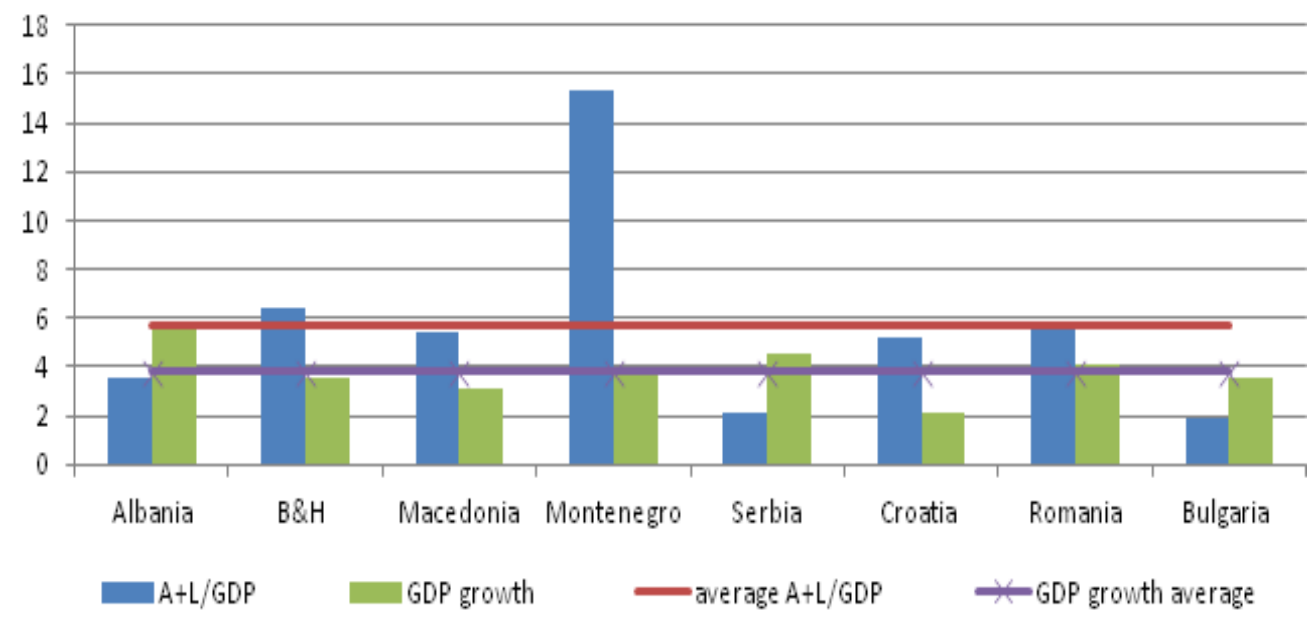

Source: IMF, International Financial Statistics

The inflows of FDI by region reveal that some transition countries from our sample have grown faster and achieved a lot of progress, in comparison to the three new members of the EU (Bulgaria, Romania and Croatia). FDIs net inflows as a \% of GDP in some countries exceeded 10 percent of GDP (i.e. Albania). Strong growth in FDIs inflows in the countries of Western Balkans from 2002 onwards was supported by the privatization of public enterprises, large-scale projects, which are largely based on a lowcost production. Looking at FDI flows by selecting countries, it can be concluded Serbia, for example, received the most FDI inflows in absolute terms, over past decade. Also, Montenegro was the first largest recipient country of FDI inflows as percentage of GDP. Montenegro and Albania became the leaders in terms of a net inflow of FDIs as percent of GDP (e.g. $10.10 \%$ of GDP and $9.6 \%$ of GDP, respectfully), ahead of Serbia with $4.33 \%$ of GDP and FYRM Macedonia (3.84\% of GDP). Although, private loans are the dominant source of funds for the domestic economy, the inflow of FDI was not negligible. If we analyze the three forms of capital inflow to the Western Balkan countries, it is 
Uluslararası Yönetim İktisat ve İşletme Dergisi, ICAFR 16 Özel Sayısı
Int. Journal of Management Economics and Business, ICAFR 16 Special Issue

evident that FDI inflows are the second important source of financing, while the inflow of portfolio investments was negligible. Also, a close analysis at the composition of capital flows reveals that in all countries of the Western Balkans as well as the EU 3 the average growth rate of FDI flows exceeded average GDP growth rates. This was mainly contributed to high rates of investment and the transfer of capital which positively affected the potential for economic growth and level of development of the countries of the Western Balkans. Table 2 shows substantial fluctuations in capital flows over time providing the Western Balkan's position vis a vis EU3 countries. Between 2005 and 2014 the average annual growth in portfolio investment was negative.

Table 2 Size and composition of capital inflows by selected countries: 2005-2014

\begin{tabular}{|c|c|c|c|}
\hline & $\begin{array}{c}\text { FDI, net inflows } \\
(\% \text { of GDP) }\end{array}$ & Loan/GDP & $\begin{array}{c}\text { Portfolio } \\
\text { Investments } \\
\text { (As \% of } \\
\text { GDP) }\end{array}$ \\
\hline \multicolumn{4}{|l|}{ Western Balkan countries } \\
\hline Standard deviations & 6.779766851 & 14.60594628 & 2.106155363 \\
\hline Mean & 8.097991406 & 45.36602491 & -0.87458 \\
\hline Median & 6.246939237 & 43.69806093 & 0.0405 \\
\hline Coefficients of variations & 0.8372 & 0.32195 & -2.4081 \\
\hline \multicolumn{4}{|l|}{ EU3 countries } \\
\hline Standard deviations & 7.21418 & 16.07714 & 2.198493 \\
\hline Mean & 6.81892 & 52.93398 & -0.372533 \\
\hline Median & 3.96612 & 59.05197 & -0.41 \\
\hline Coefficients of variations & 1.057964 & 0.3037206 & -5.9014691 \\
\hline
\end{tabular}

Source: The authors' elaborations on World Bank's World Development Indicators

In both considered the region, foreign loans and FDI have followed a similar positive trend over the entire study period (2005-2014). Foreign direct investment, net inflows (\% of GDP) in Montenegro and Serbia increased fastest among Western Balkan countries especially from 2005 to 2007 . However, with the onset of the global financial crisis the capital flows have been in decline. Portfolio investments are least represented in the structure of capital flows and unlike the other two forms of capital flows, in midcrisis and post-crisis periods the countries suffered both portfolio outflows. Also, the cyclical nature of the movement of FDI and portfolio investments was confirmed in the years of economic crisis. The recession and its effects also are reflected in a fall of FDI inflows in the period between 2008 and 2013 in almost all analyzed countries except in Albania. However, when looking at the average level of portfolio investment for the Western Balkans countries and the EU 3 countries, there is their decline and portfolio outflow that is particularly related to the financial crisis of 2007-2008. For the Western Balkan countries, median volatility of Portfolio investments (As \% of GDP) is substantially less than the median volatility of Loan-to-GDP ratio and median volatility of FDI flows-to-GDP ratio. Also, if we take into consideration of the coefficient of 


\section{Uluslararası Yönetim İktisat ve İsletme Dergisi, ICAFR 16 Özel Saylsı Int. Journal of Management Economics and Business, ICAFR 16 Special Issue}

variation for the two groups of countries, we see also that the loan-to-GDP ratio is less volatile than the FDI inflows to GDP ratio.

\section{Seeing The Outcome of Financial Deepening}

From the beginning of 2000 onwards, there has been a significant improvement in banking development of selected countries, as indicated by indicators in figure 3 (e.g. Bank credit to bank deposits) and figure 4 (e.g. Bank private credit to GDP). Crosscountry comparisons of banking sector structures measured by credit to deposit ratio in the Western Balkan region show some differences in their financial development. The reduction of this ratio at the level of the Western Balkan region took place gradually, from $169.47 \%$ in 2000 to $108.94 \%$ in 2008 and $100.67 \%$ in 2013. In 2013, the banks' average ratios of credit to bank deposits over $100 \%$ were recorded in some countries (i.e. Serbia, Bosnia and Herzegovina). In addition, US subprime mortgage crisis and its spill-over effects from Europe to the Western Balkan region influenced lower lending capacity of the banking sector as a result of weak demand for loans (with the exception of Bosnia and Herzegovina and Croatia). On the other hand, total deposits held by the banking sector in selected countries of the Western Balkan region continued to grow slowly over the same period.

Figure 3: Bank credit to bank deposits(\%), 2000-2013 Figure 4: Bank private credit to GDP (\%),2000-2013
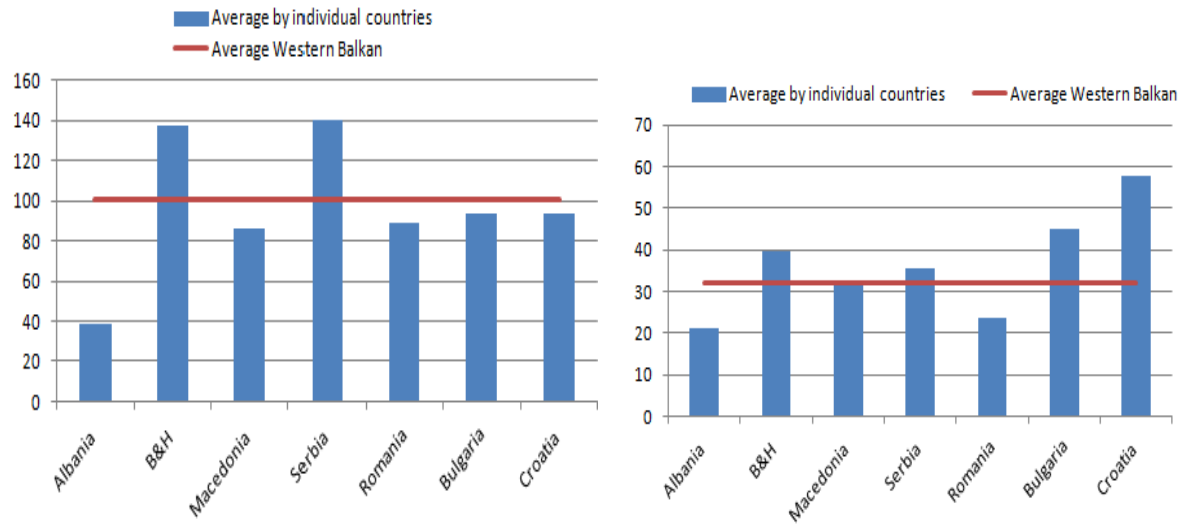

Source: The authors' elaborations on World bank data and National CBs

The sharp reduction growth in lending activity by commercial banks with a simultaneous growth of deposits in banks, has led to a decrease in the ratio of loans to deposits with $108.94 \%$ (2008) to $100.67 \%$ in 2013.

One of the best examples of the development of the banking sector, which provides comparative analyses, is the ratio of private sector credit to GDP (figure 4). The volume of banks loans to private sector as a standard indicator of financial development indicates significant differences between the countries of the Western Balkan region. While across the old EU Member States the ratio of private sector credit to GDP has grown by over $100 \%$, in the EU 3 countries (e.g. Romania, Bulgaria, and Croatia) it peaked at $33.90 \%$ in Romania and $70 \%$ in Croatia (2013). Among the other countries of the Western Balkan 


\section{Uluslararası Yönetim İktisat ve İşletme Dergisi, ICAFR 16 Özel Sayısı \\ Int. Journal of Management Economics and Business, ICAFR 16 Special Issue}

region the highest average ratio of private credit to GDP was recorded in $\mathrm{B} \& \mathrm{H}(55.90 \%$ in 2013). Its value can be considered as highly expansionary, given that in the period 2002-2013 it doubled several times. Correspondingly, by 2013 the highest values in relative terms for this indicator are recorded in Croatia, with ratio of private credit to GDP of $70 \%$, while the lowest one was recorded in Romania (33.9\%) and Albania (38\%) below average for the Western Balkan region. Moreover, the maximum share of deposits as a percentage of GDP (figure 5) between selected countries was recorded in Croatia $(68.08 \%)$ and Bulgaria (57.68\%), while the lowest in Serbia (31.34\%) and Macedonia $(33.26 \%)$.

Figure 5: Bank Deposits to GDP (\%), 2000-2013.

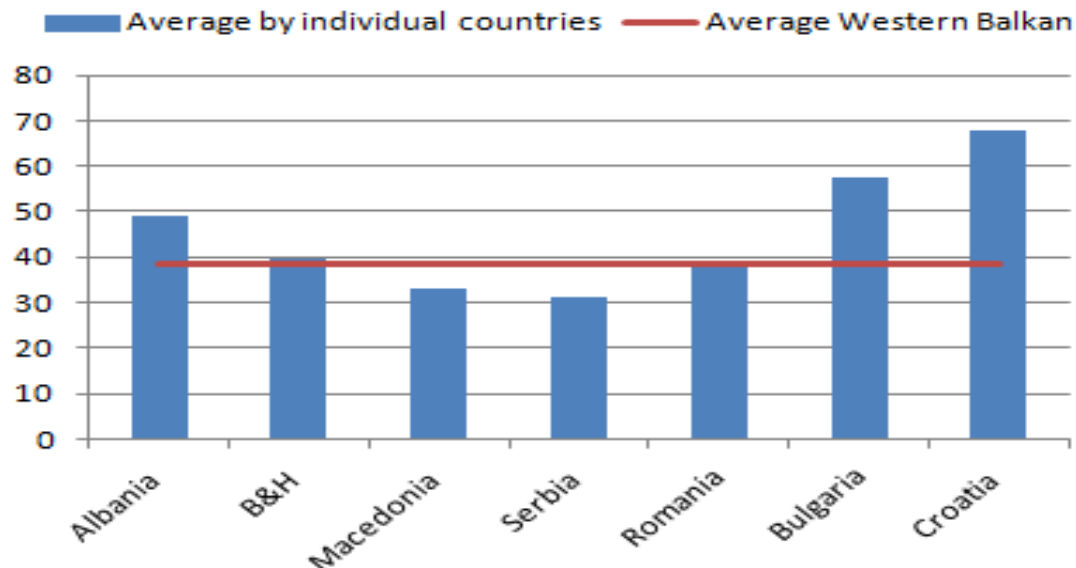

Source: The authors' elaborations on World bank data and National CBs

The reason for the lower deposits' ratio as a percentage of GDP in Macedonia and Serbia should be sought in the fact that these countries have experienced a period of hyperinflation in the middle of 1990s. As a result, there has been erosion and melting of deposits, and the decline of confidence in the banking sector. Our cross-country comparisons of average total deposits to GDP ratio reveals that the two countries from the sample (Serbia and Macedonia) are lagging significantly behind other considered countries and below Western Balkan average.

\section{Conclusion}

The process of economic and political transformation of the transition countries began in 1990s was followed by the gradual process of their financial integration with the rest of the world. The modern international financial market is characterized by the rapid development and growth of all three forms of capital inflows (FDI inflows, foreign loans and portfolio investment). Over the last 15 years, foreign capital has been flowing to the Western Balkans region in relatively moderate amounts with the intention of financing the domestic economy. The inability of the funding of domestic investment due to the low level of national savings caused that the foreign capital in the transition period was necessary to cover the country's investment needs but also funding the growing domestic demand. The financial market of the Western Balkans proved basically shallow, 


\section{Uluslararası Yönetim İktisat ve İsletme Dergisi, ICAFR 16 Özel Sayısı Int. Journal of Management Economics and Business, ICAFR 16 Special Issue}

underdeveloped, with a high concentration of the banking sector. The strong expansion of credit in transition countries prior to the start of the global financial crisis was initiated by financial deepening and the restructuring of the national financial system.

Our results show that the degree of financial integration in the region is different in the period before and after the outbreak of the global financial crisis. In fact, before the outbreak of the global financial crisis, the presence of foreign banks in the markets of the Western Balkans increased the opportunities for lending to the economy and a significant inflow of FDI.

One conclusion drawn from our comparative analyzes shows that the financial systems in sample of analyzing countries are still at an earlier stage. With the exception of Macedonia, in the rest of countries low domestic savings is not enough to finance and promote domestic investment needs. Accordingly, higher growth rate of financial openness than the economic growth rate indicates that economic growth was financed by borrowing from international financial lenders.

A second conclusion is that a high degree of financial openness can lead to a high degree of volatility in capital movements. Namely, in mid-crisis and post-crisis periods the countries of Western Balkan region as well as EU3 countries suffered both portfolio outflows. Moreover, median volatility of Portfolio investments (as \% of GDP) is shown substantially less than the median volatility of Loan-to-GDP ratio and median volatility of FDI flows-to-GDP ratio. Also, the coefficient of variation for Western Balkan region as well as EU3 countries, reveal that the loan-to-GDP ratio is less volatile than the FDI inflows to GDP ratio.

\section{References}

Alfaro, L., Chanda, A., Kalemli-Ozcan, S., \& Sayek, S. (2004). FDI and economic growth: the role of local financial markets. Journal of International Economics, 64(1), 89-112.

Aizenman, J., Jinjarak, Y., \& Park, D. (2012). Capital Flows and Economic Growth in the Era of Financial Integration and Crisis, 1990-2010. Open Econ Rev, 24(3), 371-396. Retrieved December 10, 2015, from http://dx.doi.org/10.1007/s11079012-9247-3

Brezigar-Masten, A., Coricelli, F., \& Masten, I. (2010). Financial integration and financial development in transition economies: what happens during financial crises?, Documents de travail du Centre d'Economie de la Sorbonne 10021, Université Panthéon-Sorbonne (Paris 1), Centre d'Economie de la Sorbonne. Retrieved December 1, 2015, from http://cadmus.eui.eu/bitstream/handle/1814/12673/RSCAS_2009_49.pdf?sequen ce $=1 \&$ is Allowed $=y$

Chinn, M.D., \& H. Ito. 2009. The Chinn-Ito Index: A De Jure Measure of Financial Openness. Retrieved December 1, 2015, from http://web.pdx.edu/ ito/ChinnIto_website.htm. 
Uluslararası Yönetim İktisat ve Işsletme Dergisi, ICAFR 16 Özel Saylsl Int. Journal of Management Economics and Business, ICAFR 16 Special Issue

Derado, D. (2009): Financijska integracija i financijska kriza: Hrvatska na putu prema ekonomskoj i monetarnoj uniji Financijska teorija i praksa 33 (3) str. 303-333. Retrieved November 13, 2015, from https://bib.irb.hr/prikazi-rad?\&rad=439262.

Eichengreen, B. (2001). Capital Account Liberalization: What Do Cross-Country Studies Tell Us? The World Bank Economic Review, 15(3), 341-365. Retrieved November 10, 2015, from http://dx.doi.org/10.1093/wber/15.3.341

Fama, E. \& French, K. (1989), Business Conditions and Expected Returns on Stocks and Bonds, Journal of Financial Economics, 25, 23-49.

Feldstein, M., \& Horioka, C. (1980.): Domestic Savings and International Capital Flows, Economic Journal 90, pp. 314.-329. Retrieved December 13, 2015, from http://www.nber.org/papers/w0310.pdf.

Feldstein, M., \& Horioka, C. (1991), National Saving and International Investment B. Douglas Bernheim and John B. Shoven editor, chapter 7. (pp. 201 - 226).

IMF, International Financial Statistics Yearbook, different issues. Washington: International Monetary Fund.

Lane, P., \& Milesi-Ferretti, G. (2003). International Financial Integration. SSRN Electronic Journal. http://dx.doi.org/10.2139/ssrn.495625

Lane, P., \& Milesi-Ferretti, G. (2007), "The external wealth of nations mark II: Revised and extended estimates of foreign assets and liabilities, 1970-2004", Journal of International Economics 73, November, 223-250.

Mirdala, R. (2008). Financial integration and financial deepening in the selected European transition economies, Journal of Applied Economic Sciences (JAES), Issue 6, Pages 419-433.

Ragunathan, V., Faff, R., Brooks, R. (1999.): Correlations, Business Cycles and Integration, Journal of International Financial Markets, Institutions and Money, Vol. 9, str. 75.-95.

Vo, X. V. (2005). The Determinants of International Financial Integration. SSRN Electronic Journal. http://dx.doi.org/10.2139/ssrn.932172

World Economic Outlook Database, different issues.

World Bank, World Development Indicators, different issues. 